\title{
Flexibility of Guardian and Artisan Selected Students in Solving Fraction Problems
}

\author{
R Setianingsih \\ Department of mathematics \\ Universitas Negeri Surabaya \\ Surabaya, Indonesia \\ rinisetianingsih@unesa.ac.id
}

\author{
Y F Novitasari \\ Department of mathematics \\ Universitas Negeri Surabaya \\ Surabaya, Indonesia \\ yennynovitasari@mhs.unesa.ac.ic
}

\begin{abstract}
The aim of this study is to describe flexibility of students with guardian and artisan personality types in solving fraction problems. This study is a descriptive study using qualitative approach. The subjects consisted of two 8th grade students that were measured by Personality Classification Test (PCT) and Mathematics Ability Test (MAT). Data collection methods used in this study were written tasks and task-based interviews. Then, the data were analyzed using three stages, namely, data condensation, data display, as well as drawing and verifying conclusion. The results of this study showed that the student with guardian personality type used only one strategy in solving fraction problems, namely the concept of addition and fraction multiplication, and the answers obtained are incorrect. On the other hand, the student with artisan personality type used two different strategies in solving fraction problems, namely drawing a picture, and used a variable which then obtaining correct answers. Thus, it could be concluded that student with artisan personality type is more flexible than student with guardian personality type in solving fraction problems. This study can be used as a guideline in the future assessment of flexibility of student with guardian and artisan personality types.
\end{abstract}

Keywords-flexibility, problem-solving, personality types, fraction problems

\section{INTRODUCTION}

Mathematics is a subject that has an important role in education. Along with this important role, mathematics subjects are given at all levels of education, ranging from elementary school to college. Mathematics is a tool in solving both mathematical and daily problems [1]. According to National Council of Teacher of Mathematics (NCTM), mathematics has five basic abilities, namely, communication, reasoning, problem-solving, mathematical connection, and representation. These abilities are used as the standard of students' mathematical abilities [2]. This shows a strong relationship between mathematics and problem-solving.

Learning mathematics is not enough to only teach routine procedures, but also need to train students to be flexible by getting students to work on problem-solving problems [3]. It means that students are possible to achieve maximum learning outcomes. It also indicates that mathematics learning does not only focus on improving student learning achievement, but also on improving students' flexibility in solving problems. Flexibility is a multi-strategy capability [4]. This is in line with Silver's opinion which stated that flexibility in problem solving refers to the ability of students in solving problems in one way, then by using another way [5]. In this study, problem-solving become a tool to assess students' flexibility.
The study of flexibility is generally used in specific material [6]. Students in solving non-routine problems do not make any changes of the strategy when the initial strategy used is wrong [7]. Another observation results showed that students' flexibility in solving mathematical problems had not been noticed by the teacher [8]. During the learning activities, the teacher only gives examples of solving problems related to the material that has been taught without giving a challenge to look for other possible problem-solving strategies that can be used. Some of the studies above show that aspects of student flexibility in problem-solving still need further research. This study uses fraction material as a non-routine problem to assess student flexibility because in solving that problem a student can use more than one strategy.

Personality is a pattern of certain traits that are relatively permanent in a person's behavior [9]. Personality classified into four types, namely guardian, artisan, rational and idealist [10]. This study focuses on guardian and artisan personality types. Individuals with guardian personality types are more likely to follow routine procedures with detailed instructions. While individuals with artisan personality types tend to want to show their abilities. These characteristics distinguish one student from another student. Guardians tend to choose something that is structured and organized in solving problems. While artisan tends to choose to be flexible and adaptive. Individuals with artisan personality types have a better degree of flexibility in solving problems compared to individuals with guardian personality types [11]. The results of the study on the connection ability and mathematical disposition of students explained that students' personalities influenced their flexibility in exploring mathematical ideas and tried various alternative strategies to solve mathematical problems [12]. In dealing with problems, students with guardian and artisan personality types have a different way. The statement is supported by the results of research which stated that there are differences in solving mathematical problems among students due to the different personalities of each student [13].

The description above raises the question of how flexible are students with guardian and artisan personality types in solving fraction problems. Based on the above explanation, this study was conducted to determine the flexibility of guardian and artisan selected students in solving fraction problems.

\section{RESEARCH METHODS}

This study is qualitative in nature, aiming to describe the flexibility of guardian and artisan junior high school students 
in solving fraction problem. This study was conducted at SMPN 1 Nganjuk in the even semester of the 2018/2019 academic year. The subjects in this study were two eighth grade students consisting of a student with guardian personality type, and a student with artisan personality type who had learned the material of fraction. To collect the data, the researchers used mathematical flexibility tests and interview guidelines. Then, the data were analyzed using three steps, namely, data condensation, data display, and conclusion. In order to analyze the mathematical flexibility tests in this study, the researchers used indicators of flexibility in solving problems which were adapted from Burger et al. [14].

\section{RESULT AND DISCUSSION}

\section{A. Results}

The data in this study were collected on Wednesday, 15th May 2019 by giving mathematical flexibility test to a guardian and an artisan subjects. In the same day, it continued with task-based interviews to find out the flexibility of guardian and artisan junior high school students in solving fraction problems. To analyze the flexibility of guardian and artisan students in solving fraction problems, the following indicators adapted from Burger et al. [11] are used.

TABLE I. INDICATORS OF FLEXIBILITY IN PROBLEM-SOLVING

\begin{tabular}{|c|l|}
\hline No & \multicolumn{1}{c|}{ Flexibility Indicator } \\
\hline 1 & $\begin{array}{l}\text { Select at least two different mathematical problem-solving } \\
\text { strategies }\end{array}$ \\
\hline 2 & $\begin{array}{l}\text { Implement the first strategy that has been selected until the } \\
\text { problem is resolved, or until a suggestion appears to take a } \\
\text { new action }\end{array}$ \\
\hline 3 & Implement other strategies to solve the given problem. \\
\hline
\end{tabular}

\section{1) Subject with guardian personality types}

The student with guardian personality type answered the given fraction problem as can be seen in the following answer sheet pieces.

$$
\begin{aligned}
\text { Jawab }= & \begin{aligned}
\text { Jumlah }=\frac{1}{8}+\frac{1}{56}+\frac{6}{7}=\frac{7+1+48}{56}=\frac{64}{56} & =\frac{17}{9} \times 17.000 .000=00 \\
& =3
\end{aligned}
\end{aligned}
$$

Fig. 1. Fraction addition and multiplication strategies

Fig. 1 told us that the guardian student solved the given problem by adding all parts of the inheritance of each known heir (wife, mother, and son). The guardian student also explained the strategy used in the interview as follows.

Researcher: How do you solve problems (a)? Try to explain in a coherent process that you used to complete it.

Guardian: The question asked about the total amount, so I added all parts of the inheritance of wife, mother, and son, equating the denominator to 56 all. The result is $\frac{64}{56}$ then it was simplified to become $\frac{17}{9}$. Then multiplied by the inheritance obtained by

$$
\begin{aligned}
& \text { the son. It get the result as } \frac{17}{9} \times \\
& \text { 17.000.000 }=32.111 .111 \text {. The total } \\
& \text { inheritance is Rp.32.000.000.00. }
\end{aligned}
$$

In the process of summing up there is a mistake, so that the answer obtained is incorrect. The first strategy used by guardian student was the addition and multiplication of fractions, to find the total inheritance of Mr. Aji before he distributed to his heirs (problem resolved). However, her answer is less precise. In addition, the guardian student used the second strategy to solve questions as follows.

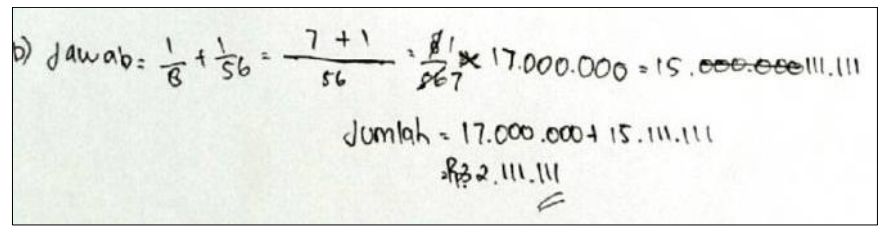

Fig. 2. Fraction addition and multiplication strategies

The guardian student solves the same problem with the same strategy as her previous strategy, namely fraction addition and multiplication (Fig. 2). This can be seen from the following interview excerpt.

Researcher : For question (b), how do you find another way of working on the problem?

Guardian : $\quad$ The answers are almost the same as point (a). It's just that the portion of the son did not add up, right away it will add up to Rp.17.000.000.00 at the end.

Researcher: Explain in a coherent process that you did to solve the problem (b) using the solution!

Guardian: The portion of the wife and mother is added up, got a result of $\frac{8}{56}$. Then, it continued to be simplified to $\frac{1}{7}$. Moreover, if it is multiplied by 17.000.000, the results would be 15.111.111. Finally, $17.000 .000+15.111 .111=$ Rp.32.111.111

Referring to the indicators in Table 1 , namely select at least two different mathematical problem-solving strategies, the guardian student only used one strategy, namely the addition and multiplication of fractions for two question points that had been done and the answers obtained were less precise for both points.

\section{2) Subject with artisan personality types}

Student with artisan personality type solving the fraction problem given can be seen in the following answer sheet. 


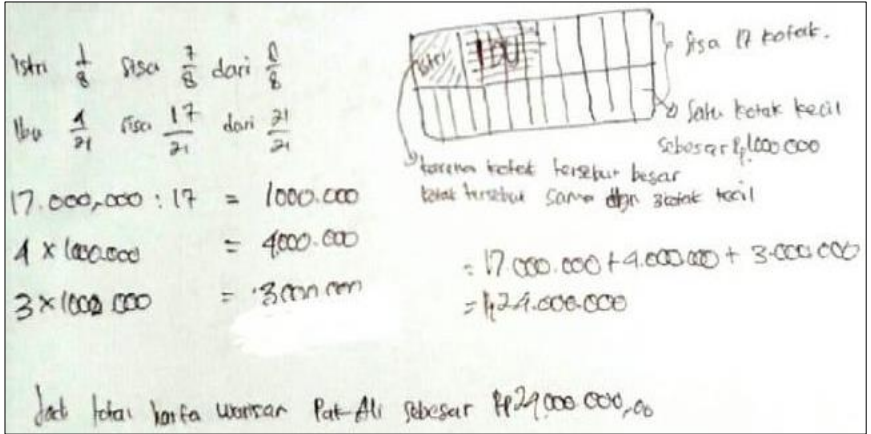

Fig. 3. Draw a picture as a strategy

Artisan student find ideas using draw a picture strategy seen in the following interview excerpt.

Researcher: What ideas did you use to solve the problem?

Artisan: I found the idea to work on the problem by imagining if the total inheritance was a big box. Then the big box was divided into small boxes for the heirs according to the part that was given in the problem.

Based on the answer sheet (Fig. 3), the artisan student solved the given problem by drawing a large rectangle representing the total inheritance of Mr. Aji. Then she divided it according to the rules of distribution of inheritance in the problem. After each part of the heirs (wife, mother, and son) was calculated, the last step was to add all parts of heirs, getting the total amount of Mr. Aji's inheritance is Rp24,000,000.00 The first chosen strategy that was used by the artisan student was drawing a picture which was done smoothly and appropriately until she found the total inheritance of Mr. Aji to be distributed to the heirs (the problem is resolved). The second strategy used to solve questions was as follows.

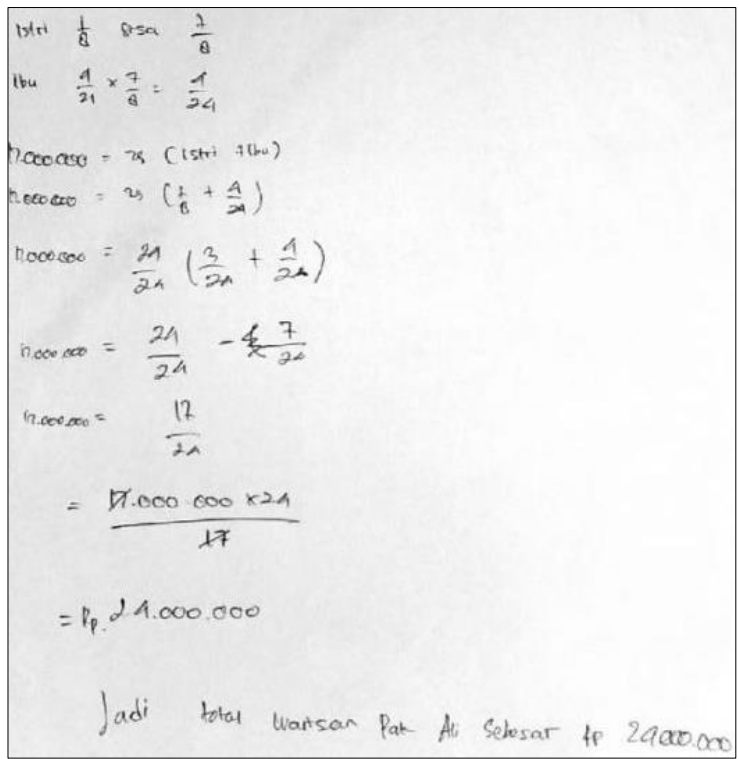

Fig. 4. Use a variable as another strategy

As can be seen in Figure 4, the artisan student works on the same problem by applying different strategy, namely, using a variable as another strategy. That statement was supported by the results of the interviews with the following artisan student.

Researcher : For question (b), how do you find another way of working on the problem?

Artisan: Learn more about the questions and answers in point $(a)$

Researcher: Explain in a coherent process that you did to solve the problem (b) using the solution.

Artisan : $\quad H i s$ wife got inheritance of $\frac{1}{8}$, the rest was $\frac{7}{8}$. His mother got $\frac{4}{21}$ times the rest of the wife. Because the mother's part was the total inheritance which was subtracted by the wife previously, this made the mother's portion became $\frac{4}{21}$ of the remaining inheritance. The result was $\frac{4}{24}$. Then used this variable $x$. The variable $x$ was originally $\mathrm{Mr}$. Aji's inheritance, initially a full one, that is $\frac{24}{24}$. Continue $\frac{24}{24}-\left(\frac{3}{24}+\frac{4}{24}\right)=\frac{24}{24}-\frac{7}{24}=\frac{17}{24}$. I got $17.000 .000=\frac{17}{24}$.

Then did it like this (pointing to the answer sheet). The result was Rp.24.000.000.00. That was Mr. Aji's total inheritance.

The artisan student's answer sheet used $x$ as a new variable to make him easy in solving problems. Referring to the indicator in Table 1, namely select at least two different mathematical problem-solving strategies, the artisan student used two different problem-solving strategies which were to draw a picture and to use a variable. Both strategies were carried out smoothly, so that the answers obtained were appropriate.

\section{B. Discussion}

Based on the results of the two subjects of this study, the relation between flexibility and personality types (guardian and artisan) becomes clear in carrying out the plan step. The solution of guardian student is in accordance with Dewiyani's statement which stated that soft skills that must be improved by guardian student types are flexible and varied in doing things, in this case is solving fraction problem [15].

The result of artisan student is in accordance with Huitt which stated that individuals with artisan personality types are more likely to be flexible and adaptive [11]. Artisan personality types have a better level of flexibility in problemsolving compared to guardian personality types. A person is supposed to have an artisan personality type if he/she behaves as sensing and perceiving. According to Keirsey, perceiving individual is someone who is more flexible and acts freely to see the various opportunities [10]. That statement is in line with the data analysis in this study. 


\section{CONCLUSIONS}

Based on the result and discussion of the data obtained during the study, the researcher may draw two conclusions as follows.

1) Student with guardian personality type is not able to show flexibility in fraction problem-solving, because he only used one strategy to solve similar mathematical problem, namely the concept of addition and multiplication of fractions. However, the results of the solution obtained were less precise.

2) Student with artisan personality type is able to show flexibility in fraction problem-solving by applying two different strategies, namely drawing a picture and using a variable. The two strategies for solving mathematical problems are carried out smoothly, so that the answers obtained are correct.

In other words, a student having artisan personality type is more flexible than one having guardian personality type in solving fraction problems. Hopefully, the results of study can be used as a guideline in the future assessment of flexibility of student having guardian or artisan personality types.

\section{REFERENCES}

[1] Sumardyono, Karakteristik Matematika dan Implementasinya terhadap Pembelajaran Matematika, Depdiknas, Yogyakarta, 2004.

[2] National Council of Teachers of Mathematics (NCTM), Principles and Standards for School Mathematics, The National Council of Teachers of Mathematics, Inc. Reston,VA, United States of America, 2000.

[3] Sugiman, Fleksibilitas Matematik dalam Pendidikan Matematika Realistik, (Online), (http://staff.uny.ac.id/sites/default/files/ 131930135/2010c_Fleksibilitas_Mat.pdf, accessed on October 23, 2018), 2010 .
[4] J. R. Star and B. R. Johnson, "Flexibility in problem solving: the case of equation solving," Journal for Learning and Instruction, Volume 18, 2007, p $565-579$.

[5] E. A. Silver, Fostering Creativity through Instruction Rich in Mathematical Problem-solving and Thinking in Problem Posing, (Online), (http://www.fiz.karlsruhe.de/fiz/publications/zdm/ zdm973a3.pdf, accessed on November 3, 2018), 1997.

[6] A. Heinze, J.R. Star, and L. Verschaffel.. "Flexible and Adaptive Use of Strategies and Representations in Mathematics Education," Zentralblatt Didaktik für Mathematik (ZDM), 41(5), 2009, p 535-540.

[7] C. Arslan and Y. Yazgan, "Common and Flexible Use of Mathematical Non Routine Problem-solving Strategies," American Journal of Educational Study, Vol. 3, No. 12, 2015, p 1519-1523.

[8] Kardiyono, Profil Fleksibilitas Siswa dalam Memecahkan Masalah Matematika Ditinjau dari Perbedaan Kemampuan Matematika dan Perbedaan Gender di SMA Negeri 9 Surabaya, Thesis not published, Unesa Pasca Sarjana Program Studi Pendidikan Matematika, Surabaya, 2012.

[9] J. Feist and G. J. Feist, Teori Kepribadian edisi 7, translation by Handrianto, Salemba Humanika, Jakarta, 2011.

[10] D. Keirsey, Please Understand Me II. Temperament Character Intelligence, Prometheus Nemesis Book Company, USA, 1998.

[11] W. Huitt, "Problem-solving and Decision Making: Consideration of Individual Differences Using the Myers-Briggs Type Indicator," Journal of Psychological Type, 24, 1992, p 33-44.

[12] A. Prasetyo, N. K. Dwidayati, and I. Junaedi, "Kemampuan Koneksi dan Disposisi Matematis Siswa Ditinjau dari Tipe Kepribadian Keirsey pada Pembelajaran Matematika Model Eliciting Activities," Unnes Journal of Mathematics Education,Vol. 6 No. 2 August 2017.

[13] F. S. Siskawati, Penalaran Siswa SMP dalam Memecahkan Masalah Matematika Ditinjau dari Perbedaan Kepribadian Ekstrovert dan Introvert, Thesis not published, Unesa Pasca Sarjana Program Studi Pendidikan Matematika, Surabaya, 2013.

[14] W. F. Burger, G. L. Musser, and B. E. Peterson, Mathematics for Elementary Teachers a Contemporary approach $8^{\text {th }}$ edition, John Wiley \& Sons, Inc. New Jersey, 2008.

[15] B. Panjaitan, "Karakteristik Metakognisi Siswa dalam Memecahkan Masalah Matematika berdasarkan Tipe Kepribadian," Jurnal Ilmu Pendidikan, Vol. 21 No.1, 2015, p 20-23. 